\title{
Article
}

\section{A Method to Use Solar Energy for the Production of Gas from Marine Hydrate-Bearing Sediments: A Case Study on the Shenhu Area}

\author{
Fulong Ning ${ }^{1,2, *}$, Nengyou Wu ${ }^{2}{ }^{*}$, Guosheng Jiang ${ }^{1}$, Ling Zhang ${ }^{1}$, Jin'an Guan ${ }^{2}$, Yibing Yu ${ }^{1}$ \\ and Fenglin Tang 1
}

1 Faculty of Engineering, China University of Geosciences, Wuhan, Hubei 430074, China;

E-Mails: jianggs65@vip.sina.com (G.J.); flyzling@yahoo.com.cn (L.Z.); guanja@ms.giec.ac.cn (J.G.); chu05@163.com (Y.Y.); fltang@cug.edu.cn (F.T.)

2 Guangzhou Center for Gas Hydrate Research, Chinese Academy of Sciences, Guangzhou 510640, China

* Author to whom correspondence should be addressed; E-Mails: nflzx@ @ug.edu.cn (F.N.); wuny@ms.giec.ac.cn (N.W.).

Received: 2 November 2010; in revised form: 16 November 2010 / Accepted: 24 November 2010 /

Published: 2 December 2010

\begin{abstract}
A method is proposed that uses renewable solar energy to supply energy for the exploitation of marine gas hydrates using thermal stimulation. The system includes solar cells, which are installed on the platform and a distributor with electric heaters. The solar module is connected with electric heaters via an insulated cable, and provides power to the heaters. Simplified equations are given for the calculation of the power of the electric heaters and the solar battery array. Also, a case study for the Shenhu area is provided to illustrate the calculation of the capacity of electric power and the solar cell system under ideal conditions. It is shown that the exploitation of marine gas hydrates by solar energy is technically and economically feasible in typical marine areas and hydrate reservoirs such as the Shenhu area. This method may also be used as a good assistance for depressurization exploitation of marine gas hydrates in the future.
\end{abstract}

Keywords: marine gas hydrates; solar energy; gas production; Shenhu area 


\section{Introduction}

Gas hydrates, also known as clathrate physical compounds [1], are crystals formed by hydrogen-bonding water in a network (the host) encapsulating gas molecules (the guest) under low temperature (normally $\leq 300 \mathrm{~K}$ ) and high pressure ( $\geq 38$ bar at $277 \mathrm{~K}$ ) conditions [2,3]. Common investigated guests are the components of natural gas, especially methane and carbon dioxide. In nature, gas hydrates, which are mainly methane hydrates, occur in permafrost and marine areas [4]. Usually, in the permafrost area, the temperatures and pressures of methane hydrate stability in sediments range from about $-7{ }^{\circ} \mathrm{C}$ to $+13{ }^{\circ} \mathrm{C}$ and 2.0 $\mathrm{MPa}$ to $10.5 \mathrm{MPa}$. They are lower than in the marine sediments, where they range from about $0{ }^{\circ} \mathrm{C}$ to $+20{ }^{\circ} \mathrm{C}$ and $6 \mathrm{MPa}$ to $60 \mathrm{MPa}$ [5]. Since gas hydrates were first found in extensive deposits in Nature, many countries have eyed this new latent energy resource, which has attributes of high energy density, large reserves, and relative cleanness. In the 21st century, with increasing shortages of energy resources and high oil and gas prices, petroleum industries have focused on finding ways for exploiting these gas hydrates. Some countries, such as the United States, Japan, Canada and China, have invested heavily to study how to exploit gas hydrates. The United States and Canada have formulated a long-term plan for studying and developing these methane hydrates. Commercial testing exploitation are expected to be operational in permafrost areas such as the Alaska North Slope and Mackenzie Delta by 2015 , and in marine methane hydrate-bearing sand reservoirs by 2025 [6]. Japan has similar plans for marine hydrates by 2016. Up to now, most gas hydrates are found in marine areas [7,8]. Klauda et al. [9] considered there was $74,400 \mathrm{Gt}$ of $\mathrm{CH}_{4}$ trapped in hydrates buried in marine zone, which were three orders of magnitude larger than worldwide conventional natural gas reserves. Therefore, the ways in which to exploit marine gas hydrates would be a hot topic for future energy research.

However, exploitation of existing marine gas hydrates is highly complicated [10], because their distributions are not like conventional deposits of oil or gas. The exploitation of marine gas hydrates would need to break the phase balance of the hydrates in some way so that the natural gas could be collected by means of its dissociation. For methane hydrate, it means that the reaction equation (1) proceeds in the right direction:

$$
\mathrm{CH}_{4} \cdot m \mathrm{H}_{2} \mathrm{O} \Leftrightarrow \mathrm{CH}_{4}+\mathrm{mH}_{2} \mathrm{O}
$$

where $\mathrm{m}$ is hydration number, i.e., the water to gas ratio in hydrates, or the number of water molecules per guest. Normally, this number is 6 for methane hydrate.

According to this concept, several methods such as thermal stimulation, depressurization, inhibitor injection, $\mathrm{CO}_{2}$ replacement, and mixing exploitation have been put forward in this field. The first three of those methods are typical [11]. Because thermal stimulation has a relatively high rate of gas production, some special and novel ideas, such as fire flooding [12], burial of nuclear wastes [13], electromagnetic heating [14], microwaves [15], downhole combustion [16,17], have also been proposed for gas hydrates exploitation, but none of them has been tried. In thermal-stimulation methods, heat is introduced into the reservoir, causing destabilization of the hydrate particles. The thermal energy may be introduced from the surface by the injection of hot fluids, like water, brine, or steam, or using a downhole process such as in situ combustion or electric and electromagnetic heating. For the depressurization method, decomposition is realized by reducing the deposits' pressure [18-22]. Normally, a well is drilled through the hydrate layer and completed in the free-gas zone. Gas 
production from this layer leads to pressure reduction and decomposition of the overlying hydrate. The hydrate exploitation of the Messoyakha field was based primarily on this depressurization technique $[1,4,11]$. This method needs no expensive continuous stimulation. Therefore, it can be an effective method for future gas-hydrate exploitation. For the inhibitor injection method, some chemicals such as methanol, ethanol, glycol, and glycerin are pumped into the sediment, which causes decomposition of gas hydrate by shifting its thermodynamic-equilibrium curve.

The three above-mentioned methods have only been tried in permafrost areas $[1,18,23-26]$ and so far have not been used in the exploitation of marine gas hydrates. This is partly related to some external factors such as the environment and marine geological hazards. But there are other disadvantages as well. For thermal stimulation, the biggest shortcomings are the great heat loss, low efficiency, and high energy consumption. Most gas hydrates are present in marine sediments in oceans that are more than $500 \mathrm{~m}$ deep, with some even attaining depths of several kilometers. This will make the hot liquid circulate in a long pipeline, with an inevitable concomitant heat loss. Although the fire flooding, burial of nuclear wastes and downhole combustion method are energy efficient, they have safety and control problems. For electromagnetic heating, basically it is a good option for heating method. However, there still exists a problem that how to get electric power when hydrate deposits are located in areas with bad infrastructure or extreme environments such as the Arctic and marine areas. Although the depressurization method can reduce energy consumption, it is significantly influenced by the manner in which the methane hydrate occurs (i.e., disseminated within sediment or in massive form) and the abundance and interconnectivity of the liquid pore water which helps to transmit the pressure decrease [6]. Inhibitor injection is also unsuitable in the ocean area. It is very expensive and pollutes the environment. $\mathrm{CO}_{2}$ replacement is also a quite attractive idea for the recovery of gas form hydrates and has become a hot issue in gas hydrate research [27]. However, this method also has some problems, such as the big cost of $\mathrm{CO}_{2}$ supply and the low replacement speed and efficiency. Therefore, it is better to combine some of these methods - for example, combining depressurization and thermal stimulation. However, energy consumption, efficiency, cost, and environmental effects are still difficulties that must be overcome in large-scale commercial exploitation.

In view of the above problems, it may be a suitable idea to use renewable energy to provide the power for the thermal stimulation and combine depressurization at the same time. It is well known that solar energy is a renewable energy [28-30], and abundant in many of the marine regions where gas hydrates accumulate, such as the Gulf of Mexico, the Blake Bahama Ridge, the Hydrate Ridge, the Nankai Trough, the South China Sea, etc. If solar energy can be collected and used to stimulate the dissociation of marine gas hydrates, the energy consumption and cost would be relatively less than the ones of conventional thermal stimulation. In our previous work [31], we proposed a concept of combining solar and geothermal energy for gas hydrates exploitation. In this work, we will give a detailed introduction on the basic principle and system composition of gas production from marine gas hydrate by using solar energy. We will also discuss the technological economics of this method based on a case study of the Shenhu area. 


\section{Solar Energy Method}

\subsection{Principle Description}

Firstly, one or several production wells are drilled in the area where the hydrates are buried, and production casings are installed and perforated to form some cavities around the borehole. Next, a solar energy generation photovoltaic system is installed on the production platform, which turns the solar energy into electric energy that will be stored in the accumulator. Some electric heaters are put into the responding cavities, they heat the gas hydrates-bearing sediment and cause hydrates to decompose. Electric energy produced by solar cells can be used for electromagnetic, microwave, or other downhole heating tools, here we select the basic type, electric resistance heater, as an example to explain this method's principle. Due to effects of differential pressure, water and gas decomposed from hydrates form a mixed fluid and flow up to the platform through the well casing. Finally the gas is collected by the gas-liquid separator.

In this concept, solar energy is first converted into electric energy, and then into heat energy, so it is not directly used as a source of heat. At present, direct thermal solar heating (similar to solar water heaters) needs bulky solar collectors and storage tanks, which would require a very large offshore platform. In addition, the efficiencies and reliabilities of solar water heaters are not very good. They often take a long time to heat water and are easily affected by the weather. Moreover, a great heat loss would occur when the heated water circulates in the injection pipes. In contrast, there is no cycle loss before stimulating hydrate decomposition by using solar cells, which could achieve "fixed point" heating and high heat efficiency (even more than 90\%) by using downhole electric heaters. Further, this indirect method can decrease the unfavorable effect of weather. The photovoltaic cells can generate redundant electric power, which can be stored in batteries and used in the rainy days, to be able to work continuously.

\subsection{System Composition}

According to the technical description, the system includes an independent electrical energy generation system fixed on an ocean platform, a downhole heating system, and a gas production system, as is shown in Figure 1.

The solar photovoltaic cell system consists of crystalline silicon panels, a controller, free-maintenance gel accumulator and a DC/AC inverter. By adopting automatic maximum power point tracking (MPPT) $[32,33]$, the battery module of the system can get maximal power under different sunlight conditions. The crystalline silicon solar cell has high conversion efficiency and a long working life, which meet the requirements for use under marine conditions, and is therefore preferred for constructing the battery module, although its cost is higher than other types such as organic/polymer solar cells, silicon thin-film cells and copper-indium selenide solar cells. The controller is for protection against overcharge and overdischarge of the accumulator, and temperature compensation. The accumulator is composed of a series of single free-maintenance gel batteries with serial and parallel hybrid connection. An electronic switch is used to control the recharge and discharge process. The accumulator works in a float-charging way and a state of repeated circulation. It is connected with the solar cell array in parallel and stores direct current (DC) generated by the photoelectric cells, and then supplies electric 
energy to the downhole heaters. Because DC is unsuitable for long-distance transmission, the inverter is needed to convert DC to alternating current (AC), so that the downhole heater can work in AC. The downhole heating system consists of a central pipe, insulated and pressure-resistant cables, electric heaters, and cavities that can hold the electric heaters. The gas production system consists of a production casing, a gas production tree on the platform, a gas-liquid separator, and a purification plant.

Figure 1. Sketch of a system for the utilization of solar energy for exploiting gas hydrates.

1. Solar photovoltaic cells; 2. Controller; 3. Maintenance-free gel accumulator; 4. Inverter; 5. Pressure gauge; 6. Insulation and pressure-resistant cables; 7. Central pipe; 8. Production casing; 9. Heater; 10. Sea floor; 11. Hydrate deposit; 12. Platform; 13. Gas production tree; 14. Cut-off valve; 15. Gas-liquid separator; 16. Water tank; 17. Purification plant; 18. Submarine pipe.

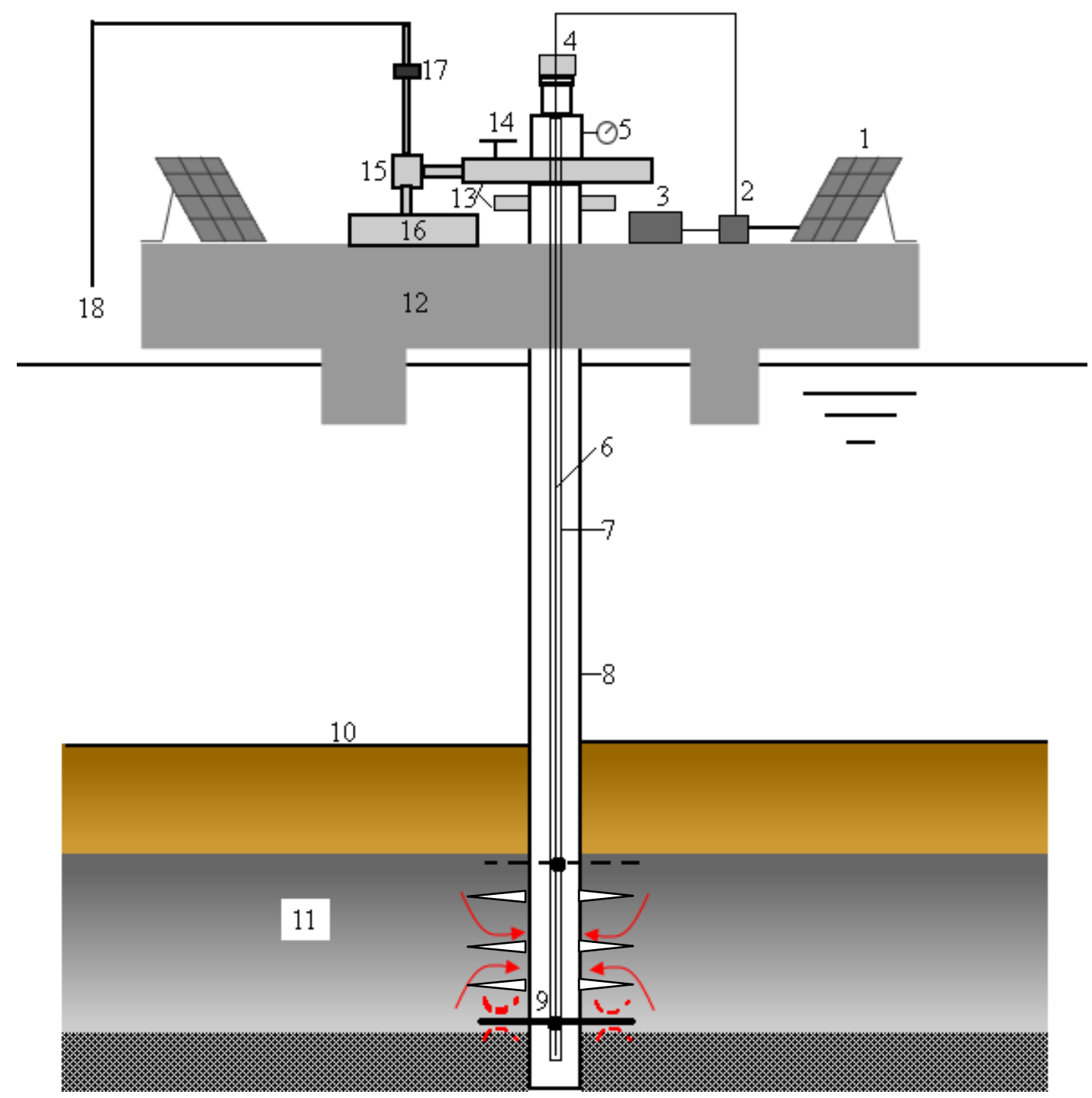

\subsection{Operational Procedures}

First a well, with a diameter of about $300 \mathrm{~mm}$ (this size is dependent on the drilling rig's capacity and the practical heater size), is drilled through the hydrate reservoir and cemented. Then the production casing is perforated near the top and bottom of the hydrate reservoir by a directional 
perforating gun to form 2-4 cavities with a depth of $20 \sim 40 \mathrm{~cm}$ and an average diameter of 3-7 cm. These cavities should lie in the top and/or bottom of the hydrate-bearing sediment, because hydrates are under the thermodynamic phase boundary at the top and bottom of gas hydrates stable zone (GHSZ). This means that less energy is required to bring the hydrates from the geothermal line to the phase boundary and that mainly the energy of dissociation is supplied. Besides, giving priority to the exploitation of hydrates that are located near the top or bottom of the GHSZ is also beneficial for the dissociation of hydrates that are located in other sections because of thermal conduction and depressurization. The circumferential interval between the cavities is constant. After the drilling, the gas production tree is installed upon the well head, and the solar energy system is set on the platform. The electric heaters are connected with the inverter and controller by the insulated and pressure-resistant cables. The number of electric heaters is $2-4$, they are designed to be explosion proof. The inner heating elements are resistances and sealed by a stainless pressure protective sleeve. The diameter of the protective sleeve is about $2-5 \mathrm{~cm}$, and its head has sharp conical shape for easy penetration. Its length can be as long as the borehole diameter permits, in order to obtain a favorable influence on the hydrate sediment. Due to depressurization and pore pressure increasing as a consequence of hydrate dissociation [34], the water and gas decomposed from hydrates move to the well. The gas expands approximately adiabatically and causes the water and itself to flow upward together in the well. When the pressure gauge shows a specific value on the gas production tree, the cut-off valve opens, and the gas-liquid mixtures enter the gas-liquid separator. Finally the separated gas is transported to the submarine pipe via the purification plant. The submarine pipeline may have been built for ordinary gas, or may be a new special pipe designed for hydrated gas transportation. The separated fresh water can be reserved in the water tank and used for production and living needs of the surrounding oil-gas-hydrate field, or it can be discharged to sea directly or reinjected into the reservoir. A pump is also set in the borehole and pumps out the initial completion fluid and subsequent decomposing water from the bottom. This behavior can effectively reduce the bottomhole pressure, increase the differential pressure between stratum and well, accelerate the dissociation of hydrates, reduce the resistance of gas flowing, and finally improve the production of gas.

The key problem that needs consideration is how exactly to deploy the heaters and how to get them out again after use conveniently under a water depth of more than $500 \mathrm{~m}$, so a conceptual distributor is designed to deploy and recover the heaters; its basic principle is illustrated in Figure 2.

The distributor consists of a screw joint, a central pipe piston, operating fluids, spring clips that are connected with the heaters, distributor pistons used to drive the clips, spacing seats of spring clips, and the springs between each two opposite distributor pistons. Firstly, the central pipe is connected with the distributor containing the heaters by the joint on the platform and then put down into the well. The springs in the distributor are in free extension condition and the central pipe piston is in the initial position. Then, a force is applied to the piston, for example by putting a weight on it, to move it downwards and discharge the operating fluid, which causes the distributor pistons to move out, then driving the spring clips and heaters to move out. 
Figure 2. Schematic diagram of the distributor. 1. Weight; 2. Central pipe piston; 3. Springs; 4. Distributor piston; 5. Spring clips; 6. Wire cable; 7. Central pipe; 8. Production casing; 9. Heater; 10. Spacing seat; 11. Distributor; 12. Cavity.

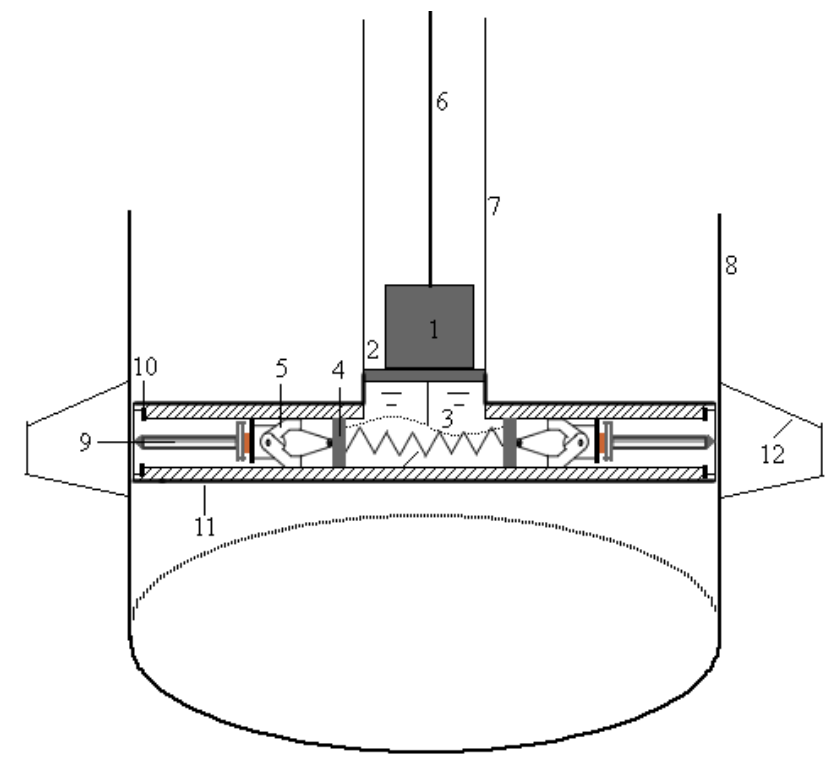

The heaters penetrate the casing and enter the cavities. When the clips move to the spacing seats, they will open and be fixed to the spacing seats. At this moment, the central pipe piston stops moving, and the tension of the springs is equal to the force that the operating fluid is applying to the distributor pistons. Hence, the force applied to the central pipe piston should ensure that the clips move exactly to the spacing seats. When the heaters need to be replaced, in case of failure, it is sufficient to just release the force or the weight, and the clips and the heaters will be retracted into the distributor under the action of the springs' tension. Then the central pipe is lifted up and the heaters can be replaced on the platform.

\section{Basic Parameters}

\subsection{Power of the Heaters}

The power of the heaters can be roughly estimated using the following steps: assume that the hydrate reservoir consists of methane hydrates, only hydrate and water exist in the pores under the initial conditions, considering that the initial quantity of gas is small. A part of the heat produced by the heaters is absorbed by the hydrates, which causes them to decompose. Another part of the heat production is absorbed by the solid matrix, hydrates, water and gas, which causes their temperature to rise. The last part are the various heat losses during the transport of heat into the depths of sediment and heat loss when gas and water from hydrate dissociation flow to the borehole. Therefore, the entire energy input of one day for the system, $\mathrm{Q}_{\text {Total }}$, can be calculated using Equation 2. This equation gives the quantity of heat that is needed to have the entire sediment (hydrate and nonhydrate) heated to various temperatures above the methane hydrate decomposition temperature: 


$$
\begin{gathered}
Q_{\text {Total }}=Q_{\text {hyd }}+Q_{\Delta T}+Q_{L}=Q_{\text {hyd }}+m_{\text {hyd }} C_{\text {hyd }} \Delta T+m_{\text {water }} C_{\text {water }} \Delta T+m_{\text {form }} C_{\text {form }} \Delta T \\
=\frac{q_{\text {meth }} \rho_{\text {meth }} H_{h}}{M_{\text {meth }} r_{g}}+\frac{q_{\text {meth }} \rho_{\text {meth }}}{M_{\text {meth }} r_{g}} \cdot\left[C_{\text {hyd }} M_{\text {hyd }}+C_{\text {water }} \cdot \frac{M_{\text {hyd }} \rho_{\text {water }} S_{\text {water }}}{\rho_{\text {hyd }} S_{\text {hyd }}}\right. \\
\left.\quad+C_{\text {form }} \cdot \frac{M_{\text {hyd }} \rho_{\text {form }}(1-\varphi)}{\rho_{\text {hyd }} S_{\text {hyd }} \varphi}\right] \cdot\left(T_{\text {eqm }}-T_{\text {form }}\right)+Q_{L}
\end{gathered}
$$

$Q_{\text {hyd: }}$ Quantity of heat needed to make hydrates decompose (J).

$Q_{\Delta T}$ : Quantity of heat needed to make the hydrate-sediment temperature increase $\Delta T$ degree $(\mathrm{J})$.

$Q_{L}$ : Various heat losses during the heating hydrate-bearing sediment (J).

$m_{\text {hyd }}$ : Mass of hydrates $(\mathrm{kg})$.

$m_{\text {water }}$ : Mass of water $(\mathrm{kg})$.

$m_{\text {form }}$ : Mass of the matrix of hydrate-bearing formation $(\mathrm{kg})$.

$C_{\text {hyd }}$ : Heat capacity of methane hydrate at constant pressure $\left(\mathrm{J} / \mathrm{kg} .{ }^{\circ} \mathrm{C}\right)$.

$C_{\text {water }}$ : Heat capacity of water at constant pressure $\left(\mathrm{J} / \mathrm{kg} .{ }^{\circ} \mathrm{C}\right)$.

$C_{\text {form }}$ : Heat capacity of the sediment matrix at constant pressure $\left(\mathrm{J} / \mathrm{kg} .{ }^{\circ} \mathrm{C}\right)$.

$q_{m e t h}$ : Average daily production (standard condition, $\mathrm{m}^{3} / \mathrm{d}$ ).

$r_{g}$ : Degree of gas recovery, $\%$.

$\rho_{\text {meth }}$ : Methane density (standard condition, $\mathrm{kg} / \mathrm{m}^{3}$ ).

$\rho_{\text {water }}$ : Water density $\left(\mathrm{kg} / \mathrm{m}^{3}\right)$.

$\rho_{\text {hyd }}$ : Density of methane hydrate $\left(\mathrm{kg} / \mathrm{m}^{3}\right)$.

$\rho_{\text {form }}$ : Density of matrix of hydrate-bearing formation $\left(\mathrm{kg} / \mathrm{m}^{3}\right)$.

$H_{h}$ : Heat of hydrate decomposition ( $\left./ \mathrm{mol}\right)$.

$M_{\text {meth: }}$ Molecular weight of methane.

$M_{\text {water: }}$ Molecular weight of water.

$M_{\text {hyd }}$ : Molecular weight of hydrate, $M_{\text {hyd }}=M_{\text {meth }}+6 M_{\text {water }}$.

$S_{\text {water }}$ : Water saturation.

$S_{\text {hyd }}$ : Hydrate saturation, $S_{h}=1-S_{w}$.

$\phi$ : Porosity of sediment.

$T_{\text {eqm }}$ : Hydrate equilibrium temperature, ${ }^{\circ} \mathrm{C}$.

$T_{\text {form }}$ : Sediment temperature, ${ }^{\circ} \mathrm{C}$.

Therefore, the power needed for each heater can be estimated by using Equation 3:

$$
P=S \cdot \frac{Q_{\text {Total }}}{3.6 \times 10^{6} \times n t \eta}
$$

$P$ : Heater power $(\mathrm{kW})$.

$S$ : Safety margin, normally range between 1.1-1.2.

$n$ : Number of heaters.

$t$ : Work time of the heater (h).

$\eta$ : Thermal-conversion efficiency of the heater, which normally has a value between 0.9-1. 
Obviously, the effective method of reducing single heater power is to decrease $\Delta T$ or to increase the number of heaters. The latter will result in a complicated distributor structure, which is not easy to maintain.

\subsection{Power of the Solar Cell Array}

After the power of the heaters is obtained by the Equation 3, we can simply calculate the capacity of the accumulator battery, the number of serial and parallel panels of the solar cell array, and the total power of the solar cell array in accord with the following steps [29,35]:

Step 1: Calculate the accumulator capacity:

$$
C_{b}=\frac{n t P N_{l} T_{m}}{C_{c} U \eta_{c}}
$$

$C_{b}$ : Capacity of the accumulator (Ah).

$U$ : Operating voltage of heaters $(\mathrm{V})$.

$N_{l:}$ The longest lasting days which are rainy/cloudy days (d)

$T_{m}$ : Correction coefficient of temperature, its value is 1 when the ambient temperature is above $0{ }^{\circ} \mathrm{C}$; it is 1.1 when the temperature is between $-10-0{ }^{\circ} \mathrm{C}$; and 1.2 when the temperature is below $-10{ }^{\circ} \mathrm{C}$.

$C_{C}$ : Depth of discharge of the accumulation, normally equal to 0.8 .

$\eta_{c}$ : Conversion efficiency of the inverter, normally equal to 0.9 .

Step 2: Calculate the number of serial panels $\mathrm{N}_{\mathrm{s}}$ :

$$
N_{s}=U_{R} / U_{o c}=\left(U_{f}+U_{D}+U_{c}\right) / U_{o c}
$$

$N_{s}$ : The number of serial panels.

$U_{R}$ : Minimum output voltage of the solar array $(\mathrm{V})$.

$U_{o c}$ : Optimum operating voltage of single module of the solar cell (V).

$U_{f}$ : Floating charge voltage of the accumulator battery $(\mathrm{V})$.

$U_{D}$ : Diode drop, normally equal to $0.7 \mathrm{~V}$.

$U_{C}$ : Voltage drop caused by other factors $(\mathrm{V})$.

Step 3: Calculate the number of parallel panels $\mathrm{N}_{\mathrm{p}}$ :

$$
N_{P}=\frac{10000 n t P\left(N_{l}+N_{w}\right)}{2.778 U H_{t} N_{w} C_{z} I_{o c} K_{o p}}
$$

$N_{p}$ : The number of parallel panels.

$N_{w}$ : Minimum number of days between two longest lasting days which are rainy/cloudy days. During this period, the power generated is not only for load working, but it is also compensating for the loss of accumulator energy which is consumed during the longest lasting days under rainy/cloudy day.

$H_{t:}$ Annual average of daily solar radiation at the water level of the hydrates-bearing zone $\left(\mathrm{kJ} / \mathrm{m}^{2}\right)$.

$C_{z}$ : Correction factor, considering the loss of combination, attenuation, dust, and controller efficiency, normally equal 0.8 . 
$I_{o c}$ : Optimum operating current of a single module of solar cell (A).

$K_{o p}$ : Coefficient of incline correction.

Step 4: Calculate the power of the solar array (unit: W):

$$
P_{S}=P_{o} \times N_{s} \times N_{P}
$$

$P_{s:}$ Power of the solar array $(\mathrm{W})$.

$P_{o}$ : Rated power of a single module of solar battery $(\mathrm{W})$.

\section{An Example from the Shenhu Arza, in the South China Sea}

\subsection{Background Information}

The Shenhu area is near the southeast of the Shenhu Underwater Sandy Bench in the middle of the north slope of the South China Sea, between the Xisha Trough and the Dongsha Islands. Tectonically the research area is located in the Zhu II Depression, Pearl River Mouth Basin (Figure 3). Since the middle Miocene it is undergoing a process of tectonic subsidence, forming good geological conditions for accumulation of gas hydrate sediments.

Figure 3. The location of the Shenhu area in the north continental slope of the South China Sea. The square region surrounded by black solid lines is the research zone in this paper.

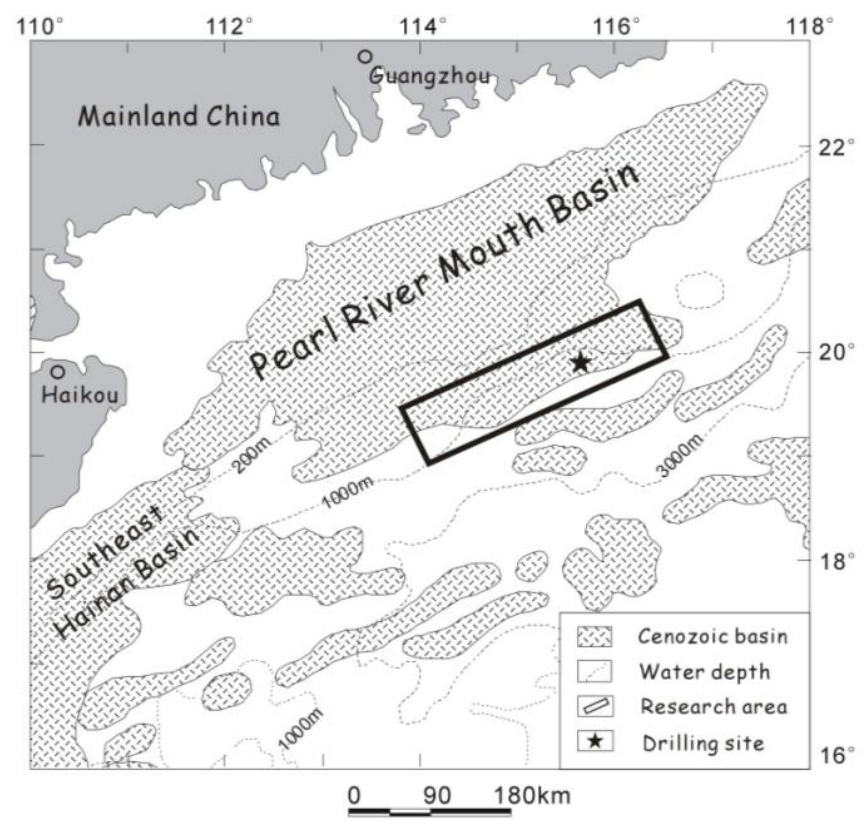

During April and June 2007, the China Geological Survey (CGS), the Guangzhou Marine Geological Survey (GMGS) and the Ministry of Land and Resources of P. R. China jointly carried out the GMGS-1 gas hydrate drilling expedition. The gas hydrate bearing sediments were sampled at sites $\mathrm{SH} 2, \mathrm{SH} 3$ and SH7 in the Shenhu area, where the water depth is over 1,200 $\mathrm{m}$ [36]. The drilling, the wireline well logging, the coring, the in-situ temperature measurements, the pore-water analysis all indicated that the gas hydrate-bearing zone in the research area was situated 183-225 m below the seafloor, that the thickness is about 18-34 m, and that the gas hydrate saturation can be $20-40 \%$, and even as high as $48 \%$ [37]. The estimated permeability of the Shenhu hydrate formation is about $10 \mathrm{mD}$. 
All the gas hydrate found during the expedition was dispersed within the pore spaces of the sediment. The sediments were predominantly clay, with a variable amount of silt-sized particles including foraminifera. Methane was the predominant gas within the core voids as well as in the gas hydrates, more than $99.7 \%$. Wu et al. [37] considered that the Shenhu gas hydrate deposit belonged to the distributed, low-flux gas hydrates, which has the same distribution characteristic as in the Blake Ridge and Hydrate Ridge. Zhang et al. [36] believed that the Shenhu gas hydrate accumulation, containing large concentrations of disseminated gas hydrate in extremely fine-grained sediments, was unique among known marine gas hydrate deposits. This occurrence of thick and uniform gas hydrate just above the bottom simulating reflector (BSR) makes the Shenhu region very appealing for studies connecting modeling of gas hydrate sediment with real field data.

\subsection{Calculations}

According to the background information, the average hydrate saturation in the Shenhu Area is about $30 \%$. The porosity of hydrates-bearing sediment is about 40\% [38]. According to the in-situ temperature measurements and core analysis of Site SH3, the hydrates-bearing sediments in the Shenhu area have an average temperature of $14.9{ }^{\circ} \mathrm{C}\left(\mathrm{T}_{\text {form }}\right)$ and an average pressure of $14 \mathrm{MPa}$. The hydrate equilibrium temperature $\left(\mathrm{T}_{\text {eqm }}\right)$ is about $15.4{ }^{\circ} \mathrm{C}$ at this pressure, calculated using Dickens' equation [39]:

$$
\frac{1}{T_{\text {eqm }}}=3.79 \times 10^{-3}-2.83 \times 10^{-4}\left(\log _{10}^{P}\right)
$$

where, $\mathrm{P}$ is the sediment pressure. According to Handa [40] and Rueff [41,42], the heat of hydrate decomposition is about $54,190 \mathrm{~J} / \mathrm{mol}$, and the specific heat of methane hydrate is about $2,500 \mathrm{~J} / \mathrm{kg} .{ }^{\circ} \mathrm{C}$ According to Cox [43], the density of methane hydrate is about $910 \mathrm{~kg} / \mathrm{m}^{3}$, so we can use the values in Table 1 to evaluate the first two parts of the heat $\mathrm{Q}_{\text {hyd }}$ and $\mathrm{Q}_{\Delta \mathrm{T}}$, and their total value is about $823 \times 10^{6} \mathrm{~J}$. It is very difficult to calculate $\mathrm{Q}_{\mathrm{L}}$, here it is simply assigned $20 \%$ of the total value of $\mathrm{Q}_{\text {hyd }}$ and $\mathrm{Q}_{\Delta \mathrm{T}}$, that is $164.6 \times 10^{6} \mathrm{~J}$, so the ideal $\mathrm{Q}_{\text {Total }}$ is $987.6 \times 10^{6} \mathrm{~J}$. If $\mathrm{S}=1.1, \mathrm{t}=24, \mathrm{n}=4$, and $\eta=0.9$, then the power needed for each heater is about $3.5 \mathrm{~kW}$. Obviously, the daily production mainly depends on the permeability of the Shenhu hydrate formation. Although the daily gas production of $10,000 \mathrm{~m}^{3} / \mathrm{d}$ did not meet the requirement for commercial production, it is still an acceptable assumption in view of the hydrate specificities and the existing technological levels. In comparison, the test gas production in the Malik hydrate project is just $2,000-4,000 \mathrm{~m}^{3}$ per day [44].

Table 1. Parameters and values of calculating the entire energy input.

\begin{tabular}{clllll}
\hline Parameter & \multicolumn{1}{c}{ Value } & Parameter & \multicolumn{1}{c}{ Value } & Parameter & Value \\
\hline$q_{\text {meth }}$ & $10,000 \mathrm{~m}^{3} / \mathrm{d}$ & $r_{g}$ & 0.8 & $\rho_{\text {meth }}$ & $0.714 \mathrm{~kg} / \mathrm{m}^{3}$ \\
$\rho_{\text {water }}$ & $1,000 \mathrm{~kg} / \mathrm{m}^{3}$ & $\rho_{\text {hyd }}$ & $910 \mathrm{~kg} / \mathrm{m}^{3}$ & $\rho_{\text {form }}$ & $2,000 \mathrm{~kg} / \mathrm{m}^{3}$ \\
$C_{\text {hyd }}$ & $2,500 \mathrm{~J} / \mathrm{kg} .{ }^{\circ} \mathrm{C}$ & $C_{\text {water }}$ & $4,200 \mathrm{~J} / \mathrm{kg} .{ }^{\circ} \mathrm{C}$ & $C_{\text {form }}$ & $880 \mathrm{~J} / \mathrm{kg} .{ }^{\circ} \mathrm{C}$ \\
$H_{h}$ & $54190 \mathrm{~J} / \mathrm{mol}$ & $T_{\text {eqm }}$ & $15.4{ }^{\circ} \mathrm{C}$ & $T_{\text {form }}$ & $14.9^{\circ} \mathrm{C}$ \\
$S_{\text {water }}$ & 0.7 & $S_{\text {hyd }}$ & 0.3 & $\phi$ & $40 \%$ \\
$M_{\text {meth }}$ & 16 & $M_{\text {water }}$ & 18 & $M_{\text {hyd }}$ & 124 \\
\hline
\end{tabular}


Because there is no meteorological station in the Shenhu area, the solar radiation data of Haikou is used to calculate the solar power system. Haikou is located at $110^{\circ} 21^{\prime} \mathrm{E}, 20^{\circ} 02^{\prime} \mathrm{N}$, has a similar latitude as the Shenhu area, and lies to the west of it (Figure 3). If $\mathrm{N}_{1}=3, \mathrm{~T}_{\mathrm{m}}=1, \mathrm{U}=220 \mathrm{~V}$, $\mathrm{C}_{\mathrm{C}}=0.8, \eta_{\mathrm{c}}=0.9$, the capacity of the accumulator $\left(\mathrm{C}_{\mathrm{b}}\right)$ is about 6,375 Ah by Equation 4 . Assuming a Model 6GFMJ200-AB gel series battery made by WuHan Intepower Co., Ltd selected as the single free-maintenance gel battery, its nominal voltage and capacity are $12 \mathrm{~V}$ and $200 \mathrm{Ah}$ at a 10 hour rate, respectively [45]. Therefore, the accumulator array consists of 32 single 6GFMJ200-AB batteries in parallel connection and 19 connections in series. The total number of this type of battery is $32 \times 19=608$. According to the records of the National Meteorological Information Centre of China Meteorological Administration, Haikou had on average 2,000 hours of sunshine per year. Figure 4 shows the monthly solar radiation of Haikou from the year 2000 to 2008 [46]. The calculated average daily solar radiation is about $13,906 \mathrm{KJ} / \mathrm{m}^{2}$. Assuming Suntech's Model STP280-24/Vd polycrystalline module is selected as the photovoltaic generation system, which has about $1.94 \mathrm{~m}^{2}$ in area, $280 \mathrm{~W}$ in power, $35.2 \mathrm{~V}$ in optimum operating voltage $\left(\mathrm{U}_{\mathrm{oc}}\right)$, $7.95 \mathrm{~A}$ in optimum operating current $\left(\mathrm{I}_{\mathrm{oc}}\right)$ and up to $14.4 \%$ in energy conversion efficiency [47]. If $\mathrm{U}_{\mathrm{f}}=230 \mathrm{~V}, \mathrm{U}_{\mathrm{D}}=0.7 \mathrm{~V}, \mathrm{U}_{\mathrm{C}}=0$, then the number of serial panels of solar array is about 7 according to Equation 5. If $\mathrm{N}_{\mathrm{w}}=30, \mathrm{C}_{\mathrm{z}}=0.85, \mathrm{~K}_{\mathrm{op}}=0.9$, then the number of parallel panels of the solar array is about 72 and the total power of the solar array is about $142 \mathrm{~kW}$ according to Equation 6 and Equation 7. Under this power condition, the number of downhole heaters this power capacity could support is four.

Figure 4. Monthly solar radiation of Haikou from year 2000 to 2008.

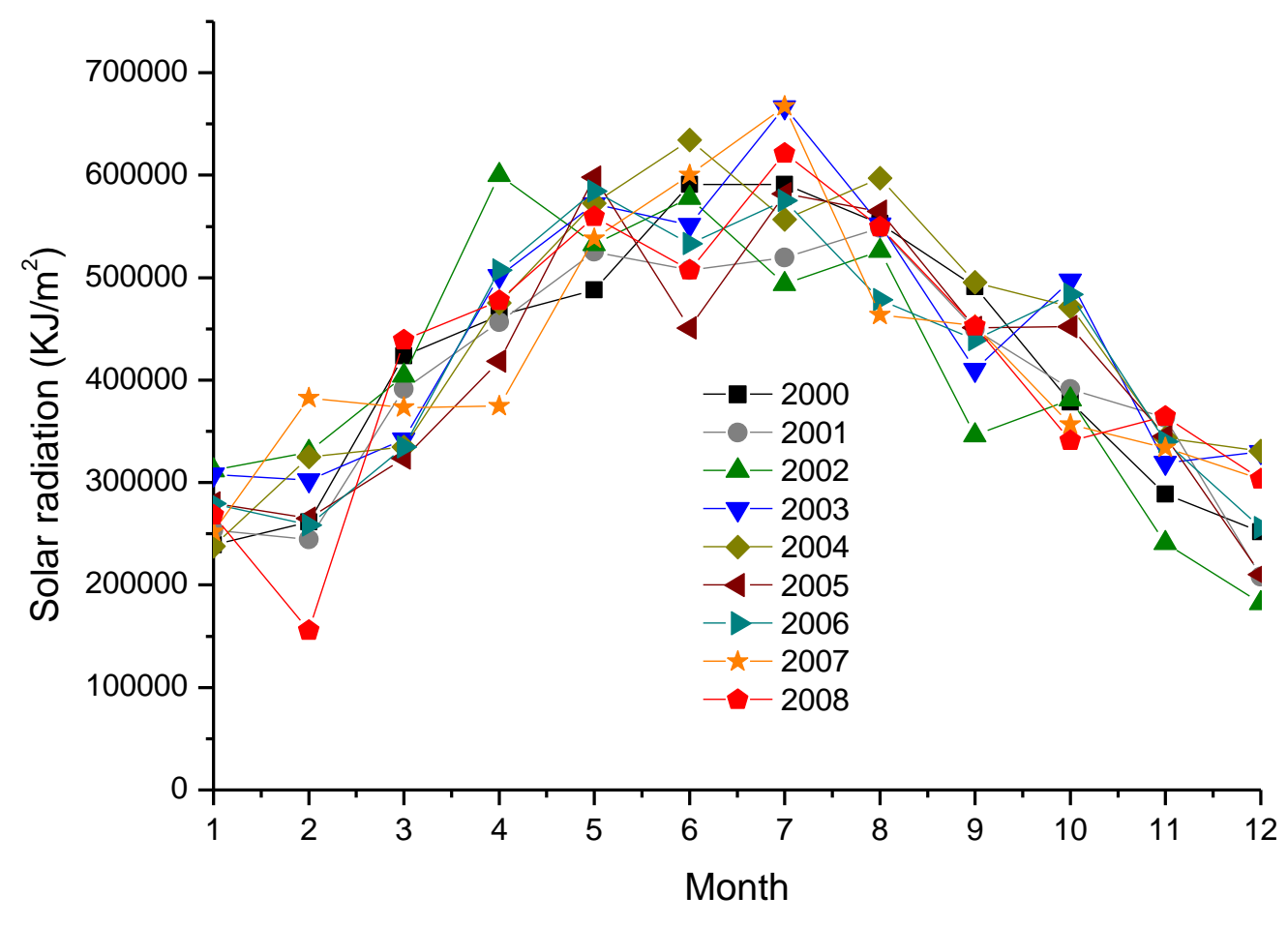

\subsection{Discussion of Technology and Economy}

Sloan and Koh use the following Equation 9 to estimate what fraction of hydrate reserves are economical to recover for energy [3]: 
$\Delta$ Hcombustion $=\Delta$ Hsensible $+\Delta$ Hdissociation

where $\Delta \mathrm{H}$ is the corresponding enthalpy. The equation shows that at $100 \%$ efficiency the energy obtained from the gas, as measured by the heat of combustion, must be equal to or greater than the sensible energy that is needed to bring the hydrates from the geothermal line to the phase boundary plus the energy of dissociation (Figure 5) [3]. Assuming that hydrates occupy 3\% of the typical pore volume of $30 \%$, a difference of $19.09 \mathrm{~K}$ between the hydrate equilibrium temperature $\left(\mathrm{T}_{\text {eqm }}\right)$ and the sediment temperature $\left(\mathrm{T}_{\text {form }}\right)$ was calculated. This means that it will be economical to recover the hydrated methane to use for energy if the hydrates' temperature is less than $19 \mathrm{~K}$ from the phase boundary. As mentioned above, the hydrates occupy $30 \%$ of the typical pore volume of $40 \%$ in the Shenhu area, which is higher than the $3 \%$ of pore volume of $30 \%$. Obviously there has a greater and permissible temperature difference which is more than $19 \mathrm{~K}$. The hydrates-bearing sediments in the Shenhu area have an average temperature of $14.9^{\circ} \mathrm{C}$ and an average pressure of $14 \mathrm{MPa}$, which is very close to the phase boundary (shown in Figure 5).

Figure 5. Compilation of data for recovered hydrate samples in relation to the three phase boundary (modified from Booth et al., [48], quoted in Reference [3]).

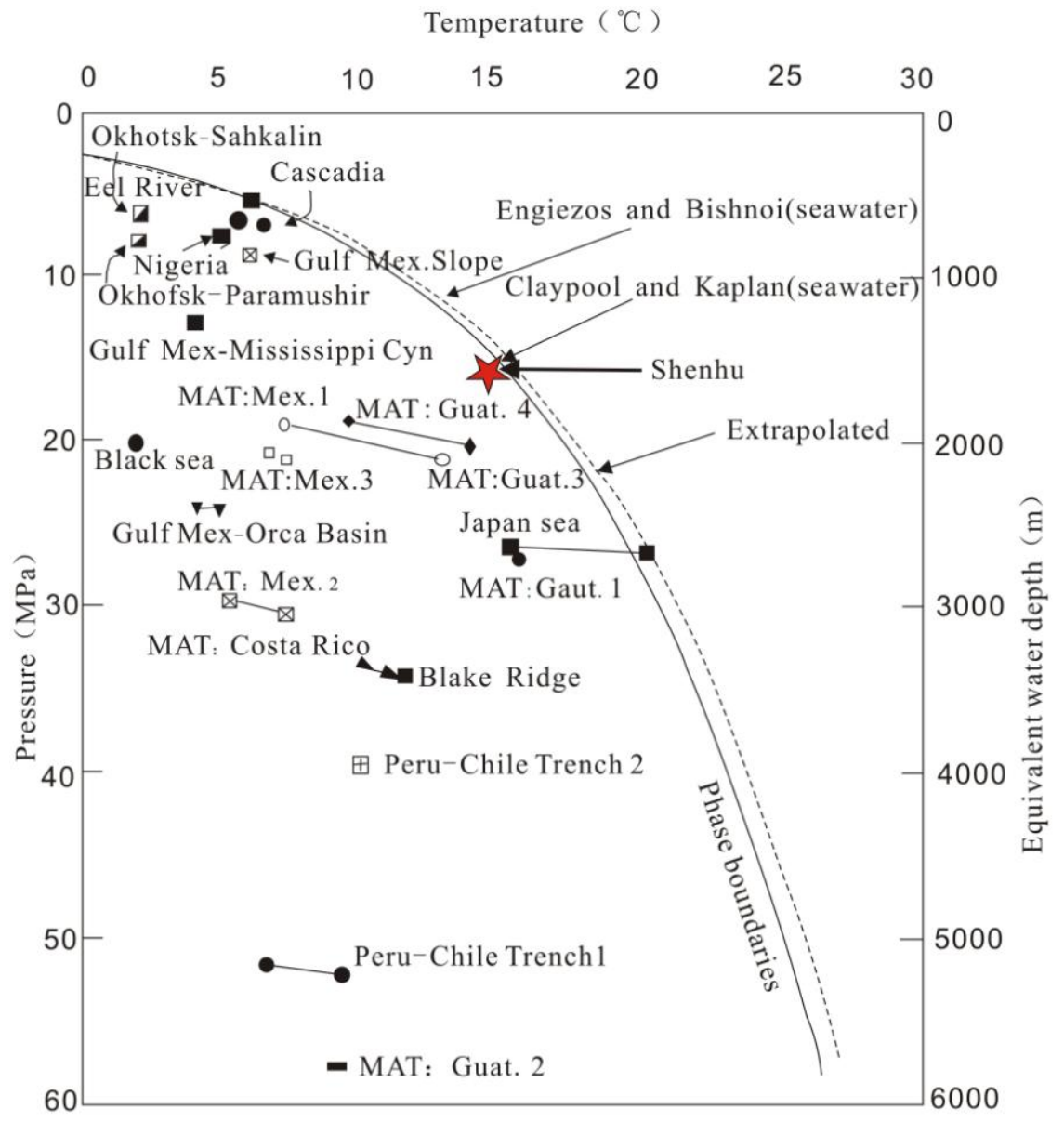

Therefore, in theory, it seems to be economical to exploit the hydrate reservoir in the Shenhu area. However, the economic evaluation of any specific project is highly dependent on the productivity of the target zone, the amount of gas in place, the natural gas price, the associated geologic and depositional environment as well as existing pipeline infrastructure, and local tariffs and taxes [49]. In 
the gas hydrate resource pyramid of Boswell and Collett [50,51], only the occurrences of methane hydrate in Arctic and marine sands, which locate at the top and second position of the pyramid, are concluded to be most concentrated and hold the greatest potential for exploitation. Walsh et al. [49] estimated that it was approximately $\$_{2008} 3 / \mathrm{Mscf}$ more expensive to produce from a Class 3 marine hydrates than a conventional marine gas reservoir of similar size and the large-scale production of natural gas from North American arctic region Class 1 and Class 2 hydrate deposits will be economically acceptable at the gas prices over $\$_{2005} 10 / \mathrm{Mscf}$ and $\$_{2005} 17 / \mathrm{Mscf}$, respectively.

For our solar energy concept, the economic evaluation is also highly dependent on the cost of solar cells and gel series batteries. Nowadays the technological breakthroughs in photovoltaics allows them to convert energy normally and continuously even under overcast skies, and solar cell prices have fallen from $\$ 27$ per watt of capacity in 1982 to less than $\$ 5$ per watt today (retail price $\$ 4.17$, August 2010 [52], so the cost of $142 \mathrm{~kW}$ solar power is about $\$ 592,000$. The price of each gel series battery is about $\$ 220$, therefore the cost of the required accumulator array is about $608 \times 220 \approx \$ 133,000$ According to the Henry Hub spot price on the August 18,2010, the price of natural gas is about $\$ 4.35$ per MMBtu [53], equivalent to $\$ 4.25 / \mathrm{Mscf}$, so a daily production of $10,000 \mathrm{~m}^{3}$ has a value of about $\$ 1,500$ and needs about 16 months to recover the cost of the solar power system without considering other factors. When using the gas price in July 2008, which is about \$13 per MMBtu [54], about five months are needed to recover the cost of the solar power system, while the cost of the platform, drilling, heaters and piping can be estimated according to the regular rules of offshore drilling. Obviously, if considering this partial cost, the given daily production of $10,000 \mathrm{~m}^{3} / \mathrm{d}$ couldn't make this concept attractive under the present gas price conditions, so in the future work we will need to determine the suitable commercial rates for daily production.

Moreover, the importance of the installation space of solar cells and the accumulator array can never be overestimated, because the deck area and space on the production platform is limited. Increasing the deck area will result in a large increase in the costs of the platform, so the spatial arrangement and the solar conversion efficiency should be considered, as well as the optimum setting angle of solar module. In this case, the total number of solar cell modules is $7 \times 72=504$, the surface area that these modules occupy is about $504 \times 1.94 \mathrm{~m} 2 \approx 980 \mathrm{~m}^{2}$. The size of single gel series battery is $0.52 \mathrm{~m} \times 0.26 \mathrm{~m} \times$ $0.237 \mathrm{~m}$ (total height), so the space occupied by the 608 batteries is less than $30 \mathrm{~m}^{3}$. The weights of each solar cell module and gel series battery are $27 \mathrm{~kg}$ and $65 \mathrm{~kg}$, so the total weight of the solar cells array and the accumulator array is about $27 \times 504+608 \times 65=53,128 \mathrm{~kg}$. Present production platforms can meet the abovementioned area, space and load bearing requirements. Especially, recently a new cylindrical solar panel was invented. It can absorb more solar energy and has less wind resistance than a plane panel [55]. It provides the same power in a smaller space and even can withstand hurricane-force winds with speeds up to $200 \mathrm{~km} / \mathrm{h}$. This is very important for solar cells to be used in offshore production platforms. Furthermore, new dye-sensitized solar cells based on diatoms could greatly increase conversion efficiency. Their efficiency can be three times as much as that of traditional solar cells [56].

In brief, amazing progress in solar energy technology is being achieved each passing day and this causes their efficiency to increase and their cost to decrease continually, while the price of natural gas is expected to reach a relatively higher level in the future because it is a nonrenewable resource and 
there is no other substitute that can replace it fully in some fields as yet. The two factors make the concept of using solar energy to produce gas from marine hydrates an attractive option in the future. The procedure and parameter calculations presented in this paper are just an example to demonstrate the feasibility of employing this method. It is obvious that well completion and electric heater deployment are two big technical challenges of this method. Electromagnetic heating or microwave heating are probably better options instead of resistance heating, taking into consideration the slower rate of heating and lower efficiency of heat transportation by using resistance heating. At the same time, they can also drastically reduce the difficulty of electric heater deployment. Lastly, this method is only appropriate for marine hydrate deposits in which the temperature of the sediment is relatively close to the hydrate phase equilibrium temperature, such as for the Cascadia and Shenhu areas shown in Figure 5. For those marine deposits in which the temperature of the sediment is far away from the hydrate phase boundary, for example the Blake Ridge, this method should not be used as the main method for gas production, but it could be used as a good complementary method to supply part of the energy for the depressurization method. Similarly, it is not recommended to use this method in the permafrost areas, because of low sediment temperatures and low amounts of solar radiation normally found in those regions. Geothermal energy might be considered as a substitute for solar energy when producing gas from methane hydrates in the permafrost area [31].

\section{Conclusions and Suggestions}

Although the recovery of gas from hydrates is considered to be a double edged sword, positive efforts are still being made to make it become reality. Unlike oil or gas reservoirs, natural gas hydrates are highly complicated in their distribution, and they don't have enough economical potential in most cases. Besides, factors such as seafloor geohazards and climate must be taken into account, making it much more difficult to exploit marine gas hydrates than conventional oil or gas deposits. Methods such as hot water stimulation, inhibitor injection and $\mathrm{CO}_{2}$ replacement are not suitable for the exploitation of gas hydrates in marine sediments because of their disadvantages and the limitations of the existing technologies. Solar energy, a clean renewable energy, can be used to effectively supply the energy demand of the thermal stimulation and depressurization methods for gas recovery from hydrates. It is converted first into electric energy, and then drives downhole heaters to produce heat energy. The downhole heaters may be resistance heaters or other downhole heating tools such as electromagnetic and microwave heaters. The number of production wells can be more than one and they can form a network. The solar array system can be deployed on the center platform, and serve as an 'energy center' or 'energy island', which supplies electric power to ambient production platforms. The above-mentioned exploitation method is technically and economically feasible if the hydrate reservoir has relatively high hydrate saturation, a low difference between the hydrate equilibrium temperature and the sediment temperature, a good permeability and a considerable solar radiation. This is the case in the Shenhu area. In the future, when problems such as gas transportation, seafloor geological hazards induced by hydrate exploitation, and global climate influence can be solved, the method can and will be adopted in the commercial exploitation of marine gas hydrates. It is also extended that the wind-solar or wave-solar hybrid system, even the geothermal energy, would be an option for supplying energy to the production of gas from marine hydrates in the future. 
It needs to be specified that, more attention is paid here to the implementation of using solar energy for the production of gas from marine hydrates-bearing sediment. The effect of hydrate dissociation, dynamics of fluids and heart transfer in porous media on the gas production are not assessed. Therefore, further work is needed to determine potential commercial rates for production, the relation between gas production and hydrate dissociation rate, properties of hydrates-bearing sediment such as conductivity and permeability, the power of electric heaters, the position of heaters, etc. At the same time, it is needed to collect the climatic data of marine places where gas hydrates occur, such as annual average temperature, wind speed, solar radiation, etc. Based on these, the design of the whole system could be optimized to improve this concept.

\section{Acknowledgments}

Our heartfelt thanks give to Yuri F. Makogon for his discussions and suggestions. We also gratefully acknowledge the financial supported by the Guangzhou Center for Gas Hydrate Research, Chinese Academy of Sciences (No.o807s2) and the National Natural Science Foundation of China (No.U0933004, 50704028). This work was also partially supported by the Fundamental Research Funds for the Central Universities" (No. CUGL100410) and Knowledge Innovation Program of Chinese Academy of Sciences (No. KGCX2-YW-805).

\section{References and Notes}

1. Makogon, Y.F. Natural gas hydrates-A promising source of energy. J. Nat. Gas Sci. Eng. 2010, 2, 49-59.

2. Sloan, E.D. Introductory overview: Hydrate knowledge development. Am. Mineral. 2004, 89, 1155-1161.

3. Sloan, E.D.; Koh, C.A. Clathrate Hydrates of Natural Gases, 3rd Ed.; CRC Press, Taylor \& Francis Group: Boca Raton, FL, USA, 2008; pp. 1-30; pp. 569-571.

4. Makogon,Y.F.; Holditch, S.A.; Makogon, T.Y. Natural gas-hydrates-A potential energy source for the 21st Century. J. Petrol. Sci. Eng. 2007, 56, 14-31.

5. These estimated temperatures and pressures are obtained by checking the Kvenvolden methane hydrate stability diagram in permafrost and ocean sediment and Booth et al. marine hydrate sample data, respectively. Please see Figure 5 and Chapter 7 of monograph in Reference3.

6. National Research Council of the National Academies. Realizing the Energy Potential of Methane Hydrate for the United States; The National Academies Press: Washington, DC, USA, 2010; p. 6.

7. Dickens GR. The potential volume of oceanic methane hydrates with variable external conditions. Org. Geochem. 2001, 32, 1179-1193.

8. Sloan, E.D. Fundamental principles and applications of natural gas hydrates. Nature 2003, 426, 353-359.

9. Klauda, J.B.; Sandler, S.I. Global distribution of methane hydrate in ocean sediment. Energy Fuels 2005, 19, 459-470.

10. Gong, J.M.; Wang, H.X.; Chen, J.W.; Wu, Z.Q.; Li, G.; Yan GJ. Distribution model for gas hydrate in sediments (in Chinese). Mar. Geol. Lett. 2004, 20, 6-8. 
11. Makogon, Y.F. Hydrates of Hydrocarbons; PennWell Publshing Co.: Tulsa, OK, USA, 1997; p. 482.

12. Halleck, P.M.; Byrer, C.W.; McGuire, P.L.; Judge, A.S.; Corlett, R.C.; Barraclough, B. In Proceedings of The Methane Hydrate Workshop, Morgantown, WV, USA, 29-30 March 1982.

13. Malone, R.D. Gas Hydrates Topical Report-DOE/METC/SP-218 (DE85001986): Morgantown (DOE, Morgantown Energy Technology Center). Technical Report for Morgantown Energy Technology Center: Morgantown, WV, USA, 1 April 1985.

14. Islam, M.R. A new recovery technique for gas production from Alaskan gas hydrates. J. Petrol. Sci. Eng. 1994, 11, 267-281.

15. Rogers, R.E. Decomposition with Microwaves. Natural Gas Hydrates Storage Project. Technical Report for Mississippi State University: Mississippi, MS, USA, 26 March 1999.

16. Castaldi, M.J.; Zhou, Y.; Yegulalp, T.M. Down-hole combustion method for gas production from methane hydrates. J. Petrol. Sci. Eng. 2007, 56, 176-185.

17. Pfefferle, W.C. Method for natural gas production. U.S. Patent 7,343,971, 18 March 2008.

18. Moridis, G.J.; Collett, T.; Dallimore, S.; Satoh, T.; Hancock, S.; Weatherhill, B. Numerical Studies Of Gas Production From Several Methane Hydrate Zones At The Mallik Site, Mackenzie Delta, Canada. J. Petrol. Sci. Eng. 2004, 43, 219-239.

19. Moridis, G.J.; Kowalsky, M.; Pruess, K. Depressurization-Induced Gas Production from Class 1 Hydrate Deposits. SPE Reservoir Eval. Eng. 2007, 10, 458-481.

20. Ji, C.; Ahmadia, G.; Smith, D.H. Natural gas production from hydrate decomposition by depressurization. Chem. Eng. Sci. 2001, 56, 5801-5814.

21. Tsypkin, G.G. Effect of decomposition of a natural gas hydrate on gas recovery from a reservoir containing hydrate and gas in the free state. Fluid Dyn. 2005, 40, 117-125.

22. Tang, L.G.; Li, X.S.; Feng, Z.P.; Li, G.; Fan, S.S. Control Mechanisms for Gas Hydrate Production by Depressurization in Different Scale Hydrate Reservoirs. Energy Fuels 2007, 21, 227-233.

23. Dallimore, S.R. Overview of the 2002 Mallik gas hydrate production research well program. In Proceedings of Fourth International Conference on Gas Hydrates, Yokohama, Japan, 19-23 May 2002. pp. 19-23.

24. Hancock, S. Overview of pressure drawdown production test results for the japex/jnoc/gsc Mallik 51-38 gas hydrate research well. In Proceedings of Mallik International Symposium, Makuhari, Japan, 8-10 December 2003.

25. Hancock, S. Overview of thermal stimulation production test results for the japex/jnoc/gsc Mallik 51-38 gas hydrate research well. In Proceedings of Mallik International Symposium, Makuhari, Japan, 8-10 December 2003.

26. Williams, T.E.; McDonald, W.J.; Millheim, K. Methane Hydrate Production from Alaskan Permafrost. Technical Progress Report for Maurer Technology Inc. (US): Sugar Land, TX, USA, 31 March 2003. No. DE-FC26-01NT41331.

27. Lee, H.; Seo, Y.; Seo, Y.T.; Moudrakovski, I.L.; Ripmeester, J.A. Recovering Methane from Solid Methane Hydrate with Carbon Dioxide. Angew. Chem. Int. Ed. 2003, 115, 5202-5205. 
28. Erdil, E.; Ilkan, M.; Egelioglu, F. An experimental study on energy generation with a photovoltaic (PV)-solar thermal hybrid system. Energy 2008, 33, 1241-1245.

29. Buresch, M. Photovoltaic Energy Systems Design and Installation; McGraw-Hill: New York, NY, USA, 1983.

30. Kelleher, J.; Ringwood, J.V. A computational tool for evaluating the economics of solar and wind microgeneration of electricity. Energy 2009, 34, 401-409.

31. Ning, F.L.; Jiang, G.S.; Zhang, L. Comprehensive utilization of geothermal and solar energy to exploit gas hydrates buried in oceanic sediments. In Proceedings of the 6th International Conference on Gas Hydrates (ICGH 2008), Vancouver, British Columbia, Canada, 6-10 July 2008.

32. Bahgat, A.B.G.; Helwa, N.H.; Ahmad, G.E.; Shenawy, E.T. Maximum power point traking controller for PV systems using neural networks. Renewable Energy 2005, 30, 1257-1268.

33. Hua, C.C.; Lin, J.G.; Shen, C.M. Implementation of a DSP-controlled photovoltaic system with peak power tracking. IEEE T. Ind. Electron. 1998, 45, 99-107.

34. $\mathrm{Xu}, \mathrm{W}$.; Germanovich, L.N. Excess pore pressure resulting from methane hydrate dissociation in marine sediments: A theoretical approach. J. Geophys. Res. 2006, 111, B01104, doi:10.1029/2004JB003600.

35. Chen, S. The simplified design of solar cell power system (in Chinese). J. Yunnan Normal Univ. 1992, 12, 104-106.

36. Zhang, H.Q.; Yang, S.X.; Wu, N.Y.; Su, X.; Holland, H.; Schultheiss, P.; Rose, K.; Butler, H.; Humphrey, G.; GMGS-1 Science Team. Successful and surprising results for China's first gas hydrate drilling expedition. Fire in the Ice. Methane Hydrate Newsletter 2007, Fall, 6-9; Available online: http://www.netl.doe.gov/technologies/oil-gas/publications/Hydrates/Newsletter/HMNews Fall07.pdf (accessed on 22 November 2010).

37. Wu, N.Y.; Zhang, H.Q.; Yang, S.X.; Liang, J.Q.; Wang, H.B. Preliminary discussion on natural gas hydrate reservoir system of Shenhu area, north slope of South China Sea (in Chinese). Nat. Gas Ind. 2007, 27, 1-6.

38. Lu, J.A.; Yang, S.X.; Wu, N.Y.; Zhang, G.X.; Zhang, M.; Liang J.Q. Well logging evaluation of gas hydrates in shenhu area, south china sea (in Chinese). Geoscience 2008, 22, 447-451.

39. Dickens, G.R.; Quinby, H. Methane hydrate stability in seawater. Geophys. Res. Lett. 1994, 21, 2115-2118.

40. Handa, Y.P. Composition, enthalpy of dissociation, and heat capacities in the range 85 to $270 \mathrm{~K}$ for clathrate hydrates of methane, ethane, and propane, and enthalpy of dissociation of isobutene hydrate, as determined by heat-flow calorimeter. J. Chem. Thermodyn. 1986, 18, 915-921.

41. Rueff, R.M. The Heat Capacity and Heat of Dissociation of Methane Hydrates: A New Approach; PhD Thesis, Colorado School of Mines, Golden, USA, 01 January 1985.

42. Rueff, R.M.; Sloan, E.D.; Yesavage, V.F. Heat capacity and heat of dissociation of methane hydrate. AIChE J. 1988, 34, 1468-1476.

43. Natural Gas Hydrates: Properties, Occurrence and Recovery, Cox, J.L., Ed.; Butterworth Publishers: Boston, MA, USA, 1983; pp. 1-125.

44. Yamamoto, K.; Dallimore, S. Aurora-JOGMEC-NRCanan Mallik 2006-2008 Gas Hydrate Research Project Progress. Fire in the Ice. Methane Hydrate Newsletter 2008, Summer, 1-5; 
Available online: http://www.netl.doe.gov/mh/HMNewsSummer08/ (accessed on 22 November 2010).

45. WuHan Intepower Co., Ltd. Available online: http://www.intepower.com/en/index.jsp (accessed on 22 November 2010).

46. National Meteorological Information Centre. Database of Year Radiation of China (since 19572008). Available online: http://cdc.cma.gov.cn/ (accessed on 22 November 2010).

47. Suntech Power. Datasheet of suntech-vd-280-275w. Available online: http://am.suntechpower.com/ images/stories/pdf/datasheets/2010/suntech-vd-280-275w.pdf (accessed on 22 November 2010).

48. Booth, J.S.; Rowe, M.M.; Fischer, K.M. Offshore gas hydrate sample database with an overview and preliminary analysis. USGS Open-File Report 96-272, 1996. Available online: pubs.usgs.gov/of/1996/of96-272/ (accessed on 22 November 2010).

49. Walsh,M.; Hancock, S.; Wilson, S.; Patil, S.; Moridis, G.; Boswell, R.; Collett, T.; Koh, C.; Sloan, E.D. Preliminary report on the economics of gas production from natural gas hydrates. In Proceedings of the 6th International Conference on Gas Hydrates (ICGH 2008), Vancouver, Canada, 6-10 July 2008.

50. Boswell, R.; Collett, T. The Gas Hydrates Resource Pyramid. Fire in the Ice. Methane Hydrate Newsletter 2006, Fall, 5-6. Available online: www.netl.doe.gov/mh/FITI06_Pyramid/ (accessed on 22 November 2010).

51. Boswell, R. Is Gas Hydrate Energy Within Reach? Science 2009, 325, 957-958.

52. SolarBuzz. Retail price survey 2010. Available online: http://www.solarbuzz.com/ (accessed on 22 November 2010).

53. U.S. Energy Information Administration. Natural Gas Weekly Update 2010. Available online: http://tonto.eia.doe.gov/oog/info/ngw/ngupdate.asp (accessed on 22 November 2010).

54. Williams, J.L. Natural Gas Futures Prices-NYMEX. WTRG Economics 2009. Available online: http://www.wtrg.com/daily/gasprice.html (accessed on 22 November 2010).

55. Kevin, B. A startup is selling cylindrical solar cells that can generate more power than conventional panels. Technology Review 2008. Available online: http://www.technologyreview.com/ energy/21473/ (accessed on 22 November 2010).

56. Johnson, R.C. Diatoms could triple solar cell efficiency. EE Times 2009. Available online: http://www.eetimes.com/showArticle.jhtml?articleID=216500176 (accessed on 22 November 2010).

(C) 2010 by the authors; licensee MDPI, Basel, Switzerland. This article is an open access article distributed under the terms and conditions of the Creative Commons Attribution license (http://creativecommons.org/licenses/by/3.0/). 